\title{
2-(4-Amino-3-methylphenyl)-5-fluorobenzothiazole is a ligand and shows species-specific partial agonism of the Aryl Hydrocarbon Receptor
}

Rana Bazzi ${ }^{\mathrm{a}}$, Tracey D Bradshaw ${ }^{\mathrm{b}}$, J. Craig Rowlands ${ }^{\mathrm{c}}$, Malcolm F G Stevens ${ }^{\mathrm{b}}$, David R Bell ${ }^{\mathrm{a} *}$ a School of Biology, University of Nottingham, University Park, Nottingham NG7 2RD, UK

b School of Pharmacy, University of Nottingham, University Park, Nottingham NG7 2RD, UK

c Toxicology and Environmental Research \& Consulting, The Dow Chemical Company, 1803

Bldg Washington Street, Midland, MI 48674 USA

Running title: benzothiazoles are ligands and partial agonists of the AhR

corresponding author David R Bell

School of Biology, University Park,University of Nottingham, Nottingham NG7 2RD. UK

Phone 441159513210

Fax 441159513251

e-mail david.bell@nottingham.ac.uk

Non-standard abbreviations.

2-(4-amino-3-methylphenyl)-5-fluorobenzothiazole, 5F 203; tetrachloroazoxybenzene, TCAOB; 2,3,7,8-tetrachlorodibenzo-p-dioxin, TCDD; dimethyl sulfoxide, DMSO; 3-(4,5Dimethylthiazol-2-yl)-2,5-diphenyltetrazolium bromide, MTT; Aryl hydrocarbon receptor, AhR; real-time polymerase chain reaction, RT-PCR; 2-(4-amino-3-acetylylphenyl)-5-fluorobenzothiazole, IH 445 


\begin{abstract}
2-(4-Amino-3-methylphenyl)-5-fluorobenzothiazole (5F 203) and related compounds are a series of anti-cancer candidate pharmaceuticals (Table 1.), that have been shown to activate the AhR. We show that these compounds are high affinity ligands for the rat AhR, but a quantitative assay for their ability to induce CYP1A1 RNA in H4IIEC3 cells, a measure of activation of the $\mathrm{AhR}$, showed a poor relationship between affinity for the AhR and ability to induce CYP1A1 RNA. 5F 203, an agonist with low potency, was able to antagonise the induction of CYP1A1 RNA by TCDD, while IH 445, a potent agonist, did not antagonise the induction of CYP1A1 RNA by TCDD, and Schild analysis confirmed 5F 203 to be a potent antagonist of the induction of CYP1A1 RNA by TCDD in H4IIEC3 cells. In contrast, several benzothiazoles show potent induction of CYP1A1 RNA in human MCF-7 cells, and 5F 203 is unable to detectably antagonise the induction of CYP1A1 RNA in MCF-7 cells, showing a species difference in antagonism. Evaluation of the antiproliferative activity of benzothiazoles showed that the ability to agonise the AhR correlated with growth inhibition both in H4IIEC3 cells for a variety of benzothiazoles, and between H4IIEC3 and MCF-7 cells for 5F 203, suggesting an important role of agonism of the AhR in the anti-proliferative activity of benzothiazoles.
\end{abstract}




\section{Introduction}

5F 203 (2-(4-amino-3-methylphenyl)-5-fluorobenzothiazole) was originally synthesised (Hutchinson et al., 2001) as part of a programme to develop novel anti-cancer drugs; these agents have potent and selective activity against a variety of tumour cell lines. The specificity of the benzothiazole series against a range of cell types suggests a novel mode of action, and a pro-drug of 5F 203 is currently in clinical trials (Bradshaw et al., 2002).

Whilst investigating the mechanism of action of these drugs, it was shown that the induction of cytochrome P450 1A1 (CYP1A1) was a key response (Chua et al., 2000), and it has been proposed that the induction of CYP1A1 causes metabolic activation of the benzothiazoles, thus causing genotoxicity (Leong et al., 2003) and thereby explaining their anti-cancer effect. The induction of CYP1A1 is known to be mediated by the Aryl Hydrocarbon Receptor (AhR) (Whitlock, 1999), a ligand-activated transcription factor. Several ligands of the AhR have been shown to have anti-cancer activity (Chen et al., 1998) (Abdelrahim et al., 2006) (McDougal et al., 1997), and interactions with the AhR may represent a mode of action for the benzothiazoles.

In agreement with this hypothesis, benzothiazoles cause nuclear translocation of the AhR, and transcriptional activation of this receptor (Loaiza-Perez et al., 2002). However, there is no published data as to whether anti-cancer benzothiazoles are ligands of the AhR. It has been reported that structurally related benzimidazole compounds can activate the AhR in the absence of ligand-binding (Dzeletovic et al., 1997) (Backlund et al., 1997) (Backlund and Ingelman-Sundberg, 2005), which appears to be a distinct mechanism of AhR activation. There is thus the possibility that benzothiazoles could activate the AhR by a non-ligand interaction with the AhR, and such a mechanism would have implications for understanding how these drugs act as anticancer agents.

We have therefore undertaken to analyse the role of the AhR in the mechanism of action of these drugs by determining the ability of these compounds to bind ligand, quantifying the ability of these drugs to activate a specific target gene of the AhR, and relating these parameters to antiproliferative activity. The data show that benzothiazoles are ligands of the AhR, and quantitative assessement of ligand-affinity and agonism reveals species-specific partial agonism of the AhR. 


\section{Methods}

Animals. Male Wistar rats CRL:WI (2-3 weeks, 200-250 g) were purchased from Charles River (UK). The animals were housed in cages under standard laboratory conditions $\left(24^{\circ} \mathrm{C}, 60 \% \mathrm{hu}-\right.$ midity, 12 hours dark/light cycle) and were given 3 days to adapt to standard laboratory conditions. These animals were used for cytosol preparation following liver perfusion.

Cell culture. Both cell lines were purchased from Sigma ECACC and culture chemicals were purchased from Sigma. The H4-II-EC3 and MCF-7 cells were cultured in modified Eagle's medium (MEM) containing sodium bicarbonate and supplemented with $10 \%$ foetal bovine serum, 1\% (200 mM L-glutamine, 10,000 U penicillin and $10 \mathrm{mg} / \mathrm{ml}$ Streptomycin) solution 100x, 1\% MEM nonessential amino acid solution 100x. The cells were cultured in a humidified atmosphere with $5 \% \mathrm{CO}_{2}$ at $37^{\circ} \mathrm{C}$.

Compounds and solutions. The radioligand $\left[{ }^{3} \mathrm{H}\right]$-2,3,7,8-tetrachlorodibenzo-p-dioxin (TCDD) (specific activity $29.8 \mathrm{Ci} / \mathrm{mmol}$ ) was from ChemSyn Laboratories. The radioligand was diluted to the working concentration $(200 \mathrm{nM})$ immediately prior to use. Unlabelled TCDD (purity 99\%) was from Cerilliant Cambridge isotope laboratories. Tetrachloroazoxybenzene (TCAOB) was a gift from Dr. Andy Smith (MRC Toxicology Unit, Leicester). Benzothiazole test chemicals were synthesised in the Cancer Research Laboratories at the University of Nottingham, UK and the Drug Synthesis and Chemistry Branch, NCI, following published methods (Hutchinson et al., 2001). Thiazolyl Blue Tetrazolium Bromide, MTT chemical, (purity 98\%), and Dextran-coated Charcoal (DCC) were purchased from Sigma.

$\left[{ }^{3} H\right]-T C D D$ standard binding assay. The radioligand binding assay is slightly modified from the classic assay (Bradfield et al., 1988), except using TCAOB (Poland et al., 1976) as a competitor. The frozen cytosolic aliquots from rat liver protein preparation were diluted in ice-cold MDENG buffer to a concentration of $5 \mathrm{mg}$ of protein $/ \mathrm{ml}$ prior to each experiment. $200 \mu \mathrm{l}$ aliquots containing receptor preparation were incubated with a range of concentration of $\left[{ }^{3} \mathrm{H}\right]$ TCDD (0-2.6 nM). In order to define the non specific binding of $\left[{ }^{3} \mathrm{H}\right]-\mathrm{TCDD}$, the same experiment was run in parallel with $1 \mu$ l of unlabelled TCAOB (200-fold molar excess of $\left[{ }^{3} \mathrm{H}\right]$-TCDD concentration) (added at least 15 minutes prior to $\left[{ }^{3} \mathrm{H}\right]$-TCDD addition to allow equilibrium to be achieved) for $16 \mathrm{~h}$ at $4^{\circ} \mathrm{C}$. Each sample was analysed in triplicate. After the $16 \mathrm{~h}$ incubation, the assay was terminated by the addition of $30 \mu \mathrm{l}$ dextran-coated charcoal ( $2 \mu \mathrm{g} / \mathrm{mg}$ protein) to remove unbound $\left[{ }^{3} \mathrm{H}\right]$-TCDD. Samples were vortexed vigorously and incubated on ice for 10 
minutes, followed by centrifugation at $20,000 \mathrm{x}$ g at $4^{\circ} \mathrm{C}$ for 10 minutes. $150 \mu \mathrm{l}$ of supernatant was analysed by liquid scintillation counting.

Competitive binding assay. The competitive assays were run in triplicate essentially under the same conditions as for $\left[{ }^{3} \mathrm{H}\right]-\mathrm{TCDD}$ standard binding assay. In order to determine the $\mathrm{IC}_{50}$ of the competitor that displaces $\left[{ }^{3} \mathrm{H}\right]$-TCDD from specific sites, $200 \mu$ cytosolic preparations \pm TCAOB $(200 \mathrm{nM}) \pm$ varying concentration of unlabelled competitor (dissolved in DMSO) were incubated for at least 15 minutes to attain equilibrium prior to addition of $1 \mathrm{nM}\left[{ }^{3} \mathrm{H}\right]-\mathrm{TCDD}$. Samples were incubated for $16 \mathrm{~h}$ at $4^{\circ} \mathrm{C}$, and $30 \mu \mathrm{l}$ of each sample was analysed for total radioactivity. After treatment with charcoal, the total and non-specifically bound $\left[{ }^{3} \mathrm{H}\right]-\mathrm{TCDD}$ in the incubations was determined by liquid scintillation spectrometry.

Chemical treatment and CYP1A1 induction protocol. Benzothiazole test chemicals and cold TCDD were prepared in dimethyl sulfoxide (DMSO) at $20 \mathrm{mM}$ and $10 \mu \mathrm{M}$ top stock solutions respectively. Prior to each experiment, concentrations were prepared in DMSO then further diluted with pre-conditioned medium into the working concentrations at the final concentration immediately before use. All experiments were conducted using the same source of each benzothiazole test chemicals and one top stock solution of TCDD that was aliquoted in Eppendorf tubes and stored at $-20^{\circ} \mathrm{C}$ for further use. For trials on TCDD and test chemicals with $10 \mu \mathrm{M}$ as the highest concentration, the final concentration of DMSO in the cultures was $0.1 \%$, whereas, for trials on test chemicals with $30 \mu \mathrm{M}$ as the highest concentration, the final DMSO concentration was $0.15 \%$. At these concentrations, DMSO was not toxic and did not increase the CYP1A1 expression above the constitutive basal levels. The general conditions consist of seeding H4-II-E cells and MCF-7 cells in triplicate wells at 1 × $10^{5}$ cells and $5 \times 10^{4}$ cells per 180 $\mu 1$, respectively, and incubated for $24 \mathrm{~h}$ at $37^{\circ} \mathrm{C}$ with $5 \% \mathrm{CO}_{2}$. The following day, confluent cultures $(90-95 \%$ confluent) were treated with vehicle control $(0.1$ or 0.15$) \%$ DMSO as a negative control, TCDD $(10 \mathrm{nM})$ as a positive control and the test inducer at the indicated concentrations for $4 \mathrm{~h}$. Chemicals were diluted into $200 \mu \mathrm{l}$ of one day pre-conditioned medium (with the exception of the experiments in Figure 2, which used fresh medium), then $20 \mu$ lof incubation medium containing the chemical was added into the well for a total volume of $200 \mu 1$. Untreated cells were included as a negative control in all experiments. To compare the maximal inducing effect for CYP1A1 mRNA for each chemical with that of TCDD, the concentration response curves for all test-chemicals were generated relative to the maximally inducing concentration of TCDD $(10 \mathrm{nM})$, set arbitrarily at 100\%. Following incubation with the indicated chemical(s), 
cultures were washed with phosphate buffered saline (PBS), treated with Trypsin/EDTA and cell pellets were washed and frozen at $-20^{\circ} \mathrm{C}$.

RNA and RT-PCR analysis. Total RNA from H4-II-E cells and MCF-7 cells was isolated, quantitated and $50 \mathrm{ng}$ was reverse transcribed into cDNA and quantitative RT-PCR analysis performed essentially as described (Bell et al., 2007), except that confluent cultures were lysed with $0.2 \mathrm{ml}$ of lysis buffer and the amount of cDNA used for multiplex PCRs was $2 \mathrm{ng}$. PCR efficiencies were empirically determined for each probe, and varied from $109-118 \%$ for rat genes and from $110-125 \%$ for human genes. The cDNA sequences of the human CYP1A1, $\beta$-actin and AhR are listed in Table 2. The three probes were analysed in the same real-time PCR reaction; CYP1A1 and AhR RNA levels are presented as a ratio to $\beta$-actin, and $\beta$-actin levels are presented as a ratio to input cDNA.

MTT assay. The general procedure is essentially as described by (Bradshaw et al., 2002). MCF7 and H4-II-E cells were seeded in triplicate into 96-well microliter plates at a density of $2.5 \mathrm{x}$ $10^{3} / 180 \mu 1$ and $5 \times 10^{3} / 180 \mu 1$ respectively and allowed $24 \mathrm{~h}$ to adhere before compounds were introduced (final concentration $0.1 \mathrm{nM}$ to $10 \mathrm{mM}, \mathrm{n}=8$ ). Absorbance was read on Wallac Victor2 plate reader (Perkin Elmer) reader at $590 \mathrm{~nm}$ as a measure of cell viability.

Curve modelling and statistical analysis. All data are represented as mean \pm SD. Statistical significance is tested by Student's t-test or one-way analysis of variance (ANOVA) followed by Dunett's Multiple Range Test. Groups were considered significantly different if $p<0.05 . K_{D}$ and $\mathrm{B}_{\max }$ were determined from non-linear regression for single site binding hyperbola analysis by GraphPad Prism 5.0 Software (GraphPad Software Inc, San Diego, CA). [ ${ }^{3}$ H]-TCDD log concentration competition curves were fitted using non linear regression for single site competitive binding analysis, $\mathrm{IC}_{50}$ values represent the concentrations of test compound required to displace $50 \%$ of $\left[{ }^{3} \mathrm{H}\right]-\mathrm{TCDD}$ specifically bound to the Ah receptor. The concentration-response curves for the CYP1A1 mRNA induction were modelled using the variable slope sigmoid Hill equation (GraphPad Prism 5.0 Software). 


\section{Results}

\section{Phenylbenzothiazoles are potent ligands for rat AhR}

Saturation analysis of $\left[{ }^{3} \mathrm{H}\right]$-TCDD binding to rat liver cytosol showed a typical saturation binding isotherm of $\left[{ }^{3} \mathrm{H}\right]-\mathrm{TCDD}$ to rat liver cytosol (Fig 1A). The apparent $\mathrm{K}_{\mathrm{D}}$ for specific binding of $\left[{ }^{3} \mathrm{H}\right]-\mathrm{TCDD}$ to rat liver cytosol and the concentration of binding sites, $\mathrm{B}_{\max }$, were $0.37 \pm 0.06$ $\mathrm{nM}$ and $\sim 40 \mathrm{fmol} / \mathrm{mg}$, respectively, over three repeats (Table 3.). The binding assay demonstrates saturable and high-affinity specific binding of $\left[{ }^{3} \mathrm{H}\right]-\mathrm{TCDD}$ to the Ah receptor, and thus the $\mathrm{K}_{\mathrm{D}}$ of $\left[{ }^{3} \mathrm{H}\right]$-TCDD can be used to determine the binding affinities of the test compounds. In order to validate the competitive binding assay, unlabelled TCDD was used to displace $\left[{ }^{3} \mathrm{H}\right]$ TCDD from specific sites (Fig 1B), with an $\mathrm{IC}_{50}$ value of $1.65 \mathrm{nM}(95 \%$ Confidence Interval, $0.66-4.1 \mathrm{nM})$, and the calculated $\mathrm{K}_{\mathrm{i}}$ for TCDD was $0.44 \mathrm{nM}(95 \% \mathrm{CI}, 0.18-11.1 \mathrm{nM})$. This is in agreement with the results of the saturation binding assay $\left(\mathrm{K}_{\mathrm{D}} 0.37 \mathrm{nM}\right)$ which confirms that the conditions under which the displacement experiment is conducted are stable and yield reproducible results as compared to the standard binding assay.

To investigate the strength of the interactions between the test compounds and AhR, competitive assays were conducted: Fig $1 \mathrm{C}$ shows the displacement of specifically-bound [ $\left.{ }^{3} \mathrm{H}\right]-\mathrm{TCDD}$ by 5F 203. The $\mathrm{K}_{\mathrm{i}}$ for 5F 203 was $2.8 \mathrm{nM}(95 \%$ CI, 2-5 nM). Thus, 5F 203 is a high-affinity ligand for AhR. Further phenylbenzothiazole analogues were assessed for their ability to compete with TCDD for binding to specific sites, and all the compounds in Table 1 yielded a $\mathrm{K}_{\mathrm{i}}<10$ $\mathrm{nM}$, showing that high affinity binding to the AhR is a common feature in this class of compounds.

\section{CYP1A1 mRNA induction assay in H4-II-E cells: time course of effects}

Given quantitative estimates of ligand-binding affinity, it was then important to develop a quantitative measure of AhR agonism in a TCDD-responsive rat cell line (Willett et al., 1998). The induction of CYP1A1 is well characterised as a measure of AhR agonism, and the time course of induction of CYP1A1 mRNA was measured, with a view to ensuring that the response was linear with time. The measurements of mRNA use normalisation against $B$-actin mRNA, therefore, it was essential to test that $\beta$-actin mRNA expression is not affected by treatment. An additional reference gene used in this study was the AhR mRNA. Fig $2 \mathrm{~B}$ and D show $B$-actin and AhR/ $\beta$-actin mRNA ratios relative to vehicle control at $4 \mathrm{~h}$. The results show that both $\beta$-actin mRNA and AhR/B-actin mRNA ratios were within two-fold after all treatments at all time 
points. This finding shows that the two reference genes can be reliably measured and do not vary with treatment or time. Thus, they are suitable to use as reference genes.

Fig 2 A reveals that TCDD significantly increased CYP1A1 mRNA levels after $4 \mathrm{~h}$ of treatment, and maximal levels of induced CYP1A1 mRNA were achieved after $12 \mathrm{~h}$ of treatment. The induction of CYP1A1 mRNA by TCDD was shown to be linear over time up to $12 \mathrm{~h}$. The time-course of the induction of CYP1A1 mRNA by 5F 203 was examined, since this compound may be metabolised. Fig 2C shows 5F 203 significantly increases CYP1A1/ß-actin mRNA ratio after $2 \mathrm{~h}$ treatment, before attaining maximal induction around 6-8 h. At $4 \mathrm{~h}$ of treatment with either TCDD or 5F 203, the induction of CYP1A1/ß-actin mRNA ratio was high enough to be measured reliably (>300-fold above control values) and was linear for both compounds. Therefore, further experiments were conducted with $4 \mathrm{~h}$ exposure of cells to compound.

\section{Induction of CYP1A1 mRNA by TCDD and benzothiazoles in H4IIEC3 cells}

In order to determine if these compounds were equally potent agonists, the concentration-response curve for induction of CYP1A1 mRNA by TCDD and 5F 203 was determined. Measurement of $\beta$-actin and AhR RNAs confirmed that variation in these genes was less than twofold from control, confirming the reliability of the PCR measurement (Fig. 3B and 3D). The $\mathrm{EC}_{50}$ value for TCDD was $60 \mathrm{pM}(95 \% \mathrm{CI}, 33-100)$ (Fig 3A), and repeat assays gave a coefficient of variation for $\mathrm{EC}_{50}$ values of $\sim 33 \%$. However, the $\mathrm{EC}_{50}$ for $5 \mathrm{~F} 203$ was $3 \mu \mathrm{M}(95 \% \mathrm{CI}$, 1.3-7.7 $\mu \mathrm{M}$ ) and the maximal levels of CYP1A1 mRNA induced by 5F 203 were not significantly different from those obtained with TCDD. Thus, 5F 203 is a full agonist in this system, but is $\sim 50,000$-fold less potent than TCDD.

In order to determine if this was a unique characteristic of 5F 203, or typical of these compounds, further phenylbenzothiazole analogues were tested for their ability to induce CYP1A1 mRNA (Fig 3C). While IH 445 is a potent inducer for CYP1A1 with an $\mathrm{EC}_{50}$ of $4 \mathrm{nM}$ (95\% confidence interval 2-10 nM), DF 203, GW 610 and AW 892 have EC $_{50}$ values in the micromolar range; thus a low potency at inducing CYP1A1 RNA is a common feature to several benzothiazoles.

A quantitative comparison between binding to $\mathrm{AhR}\left(\mathrm{K}_{\mathrm{i}}\right)$ and CYP1A1 mRNA induction $\left(\mathrm{EC}_{50}\right)$ is shown in Table 3. as the ratio. While IH 445 shows relatively good agreement between $\mathrm{K}_{\mathrm{i}}$ and $\mathrm{EC}_{50}$, the other compounds are much less potent agonists than ligands, with 5F 203 having a 
$\mathrm{K}_{\mathrm{i}}: \mathrm{EC}_{50}$ ratio 200-fold lower than $\mathrm{IH} 445$. This shows that the low- agonist potency profile manifested by some phenylbenzothiazoles is a common property for several benzothiazoles, but that it is a compound-specific characteristic, since IH 445 is a relatively potent agonist.

\section{Investigating the partial agonism of $5 F 203$}

The significant disparity between binding and induction measurements suggests two possibilities: the first is a difference in intrinsic efficacy, and the second is a difference in metabolism or excretion of the compounds. The first possibility leads to the testable hypothesis that 5F 203 would have an antagonistic effect on the ability of TCDD to induce CYP1A1. Fig 4 A shows the concentration-response curves of TCDD alone and in combination with $1 \mu \mathrm{M} 5 \mathrm{~F} 203$. TCDD had an $\mathrm{EC}_{50}$ value of $46 \mathrm{pM}(95 \% \mathrm{CI}, 13-160 \mathrm{pM})$ in the absence, and $5 \mathrm{nM}(95 \% \mathrm{CI}$, 2-12 nM) in the presence, of $1 \mu \mathrm{M} 5 \mathrm{~F} 203$; thus the $\mathrm{EC}_{50}$ for TCDD was shifted to the right by 100-fold. Maximal levels of CYP1A1 RNA induced by TCDD in the presence and absence of 5F 203 were not significantly different. IH $445\left(\mathrm{~K}_{\mathrm{i}}=0.9 \mathrm{nM}\right)$ was used as a control; since it is a potent agonist for the induction of CYP1A1 mRNA in H4-II-E cells (Table 3.), it was predicted to have no antagonistic activity on induction of CYP1A1 RNA by TCDD. H4-II-E cells were co-treated with a range of concentrations of TCDD $\pm 3 \mathrm{nM} \mathrm{IH} 445$ for $4 \mathrm{~h}$, and Fig 4E shows the $\mathrm{EC}_{50}$ for CYP1A1 mRNA induction by TCDD was not significantly different in the presence (60pM (95\% CI, 12-294)) or absence (30 pM (95\% CI, 2-400)) of $3 \mathrm{nM} \mathrm{IH} \mathrm{445,} \mathrm{and} \mathrm{thus}$ there was no detectable antagonistic activity of IH 445. The related benzothiazole IH 445 fails to show detectable antagonism in this assay, and thus this demonstrates that the inhibition of induction of CYP1A1 RNA is not a non-specific consequence of the phenylbenzothiazole structure, but is chemical-specific. In summary, this experiment provides powerful evidence for excluding the possibility that poor availability of the 5F 203 could be the major reason behind the large quantitative difference in potency between 5F 203 and TCDD; if most of the 5F 203 were metabolised and/ or excreted, one would expect that there would be no change in potency of TCDD.

\section{Schild regression analysis}

Fig 4 A shows that 5F 203 inhibited the induction of CYP1A1 mRNA by TCDD, but does not necessarily prove that this inhibition is competitive. To unravel the nature of this antagonism, Schild regression was performed. Fig. 4D shows that $\beta$-actin and AhR RNA levels only show minor variation over the range of experimental conditions, and demonstrate the reliability of 
RT-PCR determinations. Fig 4 C shows the log concentration-response curves of CYP1A1 mRNA by TCDD alone, and in combination with varying concentrations of $5 \mathrm{~F} 203$. The $\mathrm{EC}_{50}$ of TCDD for CYP1A1 mRNA induction was measured at each concentration of 5F 203, and non-linear Schild regression analysis demonstrated a Schild slope of $\sim 1$ (95\% CI, 0.5-1.8), and that the $\mathrm{K}_{\mathrm{B}}$ for $5 \mathrm{~F} 203$ was $23 \mathrm{nM}$ (95\% CI, 4-139). Thus antagonism by 5F 203 of the induction of CYP1A1 RNA by TCDD is not allosteric nor non-competitive but competitive. The $\mathrm{K}_{\mathrm{B}}$ is within 3 -fold of the $\mathrm{IC}_{50}$ value determined by competitive binding assay fig $1 \mathrm{C}$, and so the low potency of 5F 203 for inducing CYP1A1 mRNA in H4-II-E cells was shown to be a result of its antagonistic activity.

\section{Induction assays in human MCF-7 cells}

The ability of 5F 203 to act as an antagonist of TCDD at inducing CYP1A1 in human cells was investigated; MCF-7 cells were used since these showed inducibility of CYP1A1 by TCDD (Christou et al., 1994) and 5F 203 (Brantley et al., 2004). Fig.s 5B and D show that there was no significant difference in $\beta$-actin or AhR RNAs under the range of experimental conditions tested. Fig 5A shows the concentration-response curves for TCDD and 5F 203 in MCF-7 cells. CYP1A1 mRNA was highly induced by 5F 203 and TCDD ( 1600- and $\sim 1700$ - fold above vehicle control, respectively). The $\mathrm{EC}_{50}$ value for TCDD was $0.2 \mathrm{nM}(95 \% \mathrm{CI}, 0.07-0.6)$, and for 5F 203 was $2 \mathrm{nM}$ (95\% CI, 0.9-5), only 10-fold less potent than TCDD. These results are in contrast to the marked difference in potency in rat cells.

The antagonistic activity of 5F 203 was investigated in MCF-7 cells by co-exposing cultures to increasing concentrations of TCDD \pm 500 pM 5F 203 (Fig 5C). From fig 5C, the $\mathrm{EC}_{50}$ for TCDD in the absence of 500 pM 5F 203 was 300 pM (95\% CI, 98-930] whereas in the presence of 500 pM 5F 203, the $\mathrm{EC}_{50}$ for TCDD was 400 pM (95\% CI, 250-700), which was not significantly different. Thus 5F 203 had no detectable antagonistic activity on the induction of CYP1A1 RNA by TCDD in human MCF-7 cells.

\section{Investigating the antiproliferative activity of benzothiazoles in MCF-7 and H4-II-E cells}

Given the marked difference in ability of phenylbenzothiazoles to antagonise AhR between human MCF-7, and rat H4-II-E, cells, the antiproliferative activity of phenylbenzothiazole analogues was characterised in these cell lines using the MTT cell viability assay (Table 4.). Camptothecin was used as a positive control, and gave potent growth inhibition in MCF-7 cells (19 nM, 95\% CI 6-56 nM) (Fig 6B). 5F 203 and IH 445 decreased growth in MCF-7 cells with 


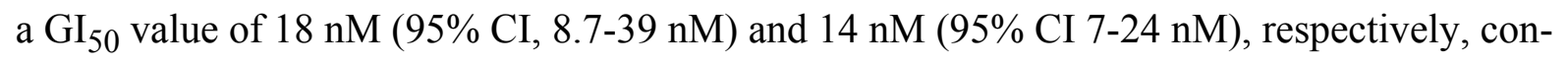
sistent with previous reports (Hutchinson et al., 2001) (Bradshaw et al., 2002). TCDD treatment did not affect cell growth at any concentration tested and confirms that agonism of the AhR by TCDD per se has no inhibitory activity in MCF-7 cells.

H4-II-E cells were treated with these chemicals to investigate the antiproliferative activity of these compounds, using the same MTT assay (Table 4.). Fig 6 A shows that the positive control compound, camptothecin, had a $\mathrm{GI}_{50}$ of $67 \mathrm{nM}(95 \% \mathrm{CI}, 12-386 \mathrm{nM})$, and at concentrations $\geq$ $100 \mathrm{nM}$ was cytotoxic, whereas TCDD did not inhibit cell growth at any concentration tested. 5F 203 failed to inhibit the growth of the cells up to $10 \mu \mathrm{M}$, the limit of solubility. In contrast, IH 445 was found to inhibit cell growth, with a $\mathrm{GI}_{50}$ value of $100 \mathrm{nM}(95 \% \mathrm{CI}, 40-248 \mathrm{nM})$. Thus the ability to agonise at the AhR correlated with anti-proliferative activity of benzothiazoles both across species (rat vs human cell lines) and within a species (5F 203 vs. IH 445). 


\section{Discussion}

The ability of 5F 203 to displace specifically-bound TCDD from cytosol at nanoMolar concentrations characterises this phenylbenzothiazole as a high-affinity ligand of the AhR, and provides a basis for understanding the reported ability of this compound to activate the AhR (Trapani et al., 2003) (Loaiza-Perez et al., 2002). The high affinity of several of these chemicals in displacing specifically-bound cytosolic TCDD shows that this is a new series of ligands for the AhR that raise interesting questions about the structural requirements for binding to the AhR. SAR based upon the dioxin and furan series of ligands suggest a requirement for planarity and halogen atoms in the lateral position (Safe et al., 1986) (Poland and Knutson, 1982), but both of these shibboleths are questioned in the phenylbenzothiazole series, since 5F 203 is neither an obligate planar molecule (although it can assume a planar conformation), nor does it have exclusively lateral halogen atoms. The differences between the dioxin/ furan series, and phenylbenzothiazoles are not simply explained by conspicuously low affinity of the latter compounds, since the affinity of 5F 203 and TCDD for AhR are within ten-fold. Thus this series of compounds provides evidence for the possibility that a much wider range of compounds may be high affinity ligands for AhR (Henry et al., 2006).

The affinity for binding to AhR has been shown to be predictive for the ability of dioxins and furans to activate AhR (Poland and Knutson, 1982), and so we envisaged testing if this relationship held true for benzothiazoles. In order to make a quantitative evaluation of agonism, the RTPCR assay was designed to take samples at an early stage after dosing, thus minimising the effects of metabolism of compound, whilst showing a linear response to compound with time. Under these circumstances, TCDD had an $\mathrm{EC}_{50}$ for inducing CYP1A1 RNA of $60 \mathrm{pM}$, comparable with previous studies (Sawyer and Safe, 1982). It was unexpected that the assay for induction of CYP1A1 RNA would yield such a large disparity between affinity and agonistic activity for 5F 203. It is of interest that $\mathrm{IH} 445$, which has a lateral alkyne group on the benzene ring (as opposed to the 3' methyl group), is almost $\sim 1000$-fold more potent than the other benzothiazoles tested in this assay, suggesting a key role for the 3' substituent in the agonism of AhR.

The low potency of 5F 203 in agonising the AhR may be explained through decreased bio-availability of the compound, partial agonism, or non-competitive activation of an alternative pathway that inhibits the AhR signalling pathway. The ability of 5F 203 to inhibit the induction of CYP1A1 by TCDD provides compelling evidence that 5F 203 is available within the cell, and that decreased bioavailability of the compound is not the principal reason for its low potency. 
The ability to measure the antagonistic ability of an AhR ligand by Schild assay provides a quantitative measure of antagonism, and proves that the effect of 5F 203 is competitive with TCDD, and therefore is mediated through the AhR signalling pathway. Schild assay has previously been used to demonstrated that PCB 128 is a competitive antagonist of the fish AhR (Hestermann et al., 2000). It is apparent that several AhR ligands exhibit both agonistic and antagonistic activities (Zhou and Gasiewicz, 2003) (Palermo et al., 2003) (MacDonald et al., 2004) (de Medina et al., 2005), and classical receptor theory predicts that partial agonists will cause different levels of response, dependent upon receptor number and receptor-coupling (Kenakin, 1997); indeed, cell-specific response to partial agonists of AhR has been demonstrated (Zhang et al., 2003). The relative quantification of these activities is essential for understanding how AhR receptor number and coupling are related to the physiological and toxicological consequences of exposure to AhR ligands.

The induction of CYP1A1 RNA is a highly sensitive marker of AhR activation (Bell et al., 2007), and measurement of CYP1A1 RNA provides a quantitative measure of AhR activation, that is arguably superior to measuring P450 protein activity, since effects such as regulation of translation, or inhibition of enzyme activity, can vitiate interpretation, and the effects of compound metabolism can be minimised by measuring response at an early time point. This assay thereby enables a quantitative comparison between agonistic and antagonistic activities of AhR ligands. This represents an important advance, insofar as a great deal of existing literature describes antagonism of the AhR in a qualitative manner, and quantitative measurements will enable insight into the molecular mechanisms underlying ligand-specificity of response. So for example, where there is differential recruitment of cofactors by ligands of AhR (Boronat, 2007) (Hestermann and Brown, 2003) (Zhang et al., 2008), it would be of interest to quantitate the agonistic and antagonistic activity of the ligands.

This report shows that 5F 203 exhibits principally antagonistic effects on the rat AhR, whilst no measurable antagonistic activity of 5F 203 can be detected in the human, MCF-7 cell line.

Whilst this difference between rat and human cell lines could theoretically be ascribd to differences in receptor number or receptor coupling (Kenakin, 1997), direct measurements of AhR protein in these cell lines argues against a determinative role for receptor number (Holmes and Pollenz, 1997), and the similar $\mathrm{EC}_{50}$ for induction of CYP1A1 by TCDD between these two cell lines (Fig. 2, 5) argues that receptor-coupling is similar between the two cell lines. Species differences in the AhR (Ema et al., 1994) itself is the most plausible explanation for the ability of 
5F203 to inhibit the induction of CYP1A1 by TCDD by $>100$-fold in rat cells, as opposed to no measurable antagonism in human cells. In agreement with the lack of antagonism of 5F 203 in human cells, 5F 203 is a potent agonist in MCF-7 cells, with an $\mathrm{EC}_{50}$ of $2.2 \mathrm{nM}, 1000$-fold more potent than in rat H4IIEC3 cells. Species-specific differences in partial agonism have been characterised before between mouse and guinea-pig (Zhou et al., 2003), and this work shows that these are possible between human and other species, and extends the concept by showing quantitative differences between rat and human cells. Given the significant differences in the ligandbinding affinity of AhR for TCDD that has been shown between mouse/rat and human as a result of the A381V residue (Ema et al., 1994) (Poland et al., 1994), it will be of interest to determine if this residue can also confer differences in partial agonism.

It has been proposed that the induction of CYP1A1 by 5F 203 is a key function of the anti-proliferative activity of this compound (Trapani et al., 2003). Given that the partial antagonism of AhR by benzothiazoles will inhibit the induction of CYP1A1, we postulated that the antagonistic activity of compounds would correlate with anti-proliferative activity both in rat cells, and when comparing rat and human cells. Thus the agonist IH 445 is relatively potent as a cytostatic agent in rat cells, while 5F 203 does not significantly decrease growth in the same rat cell line (Table 4.); 5F 203 also failed to exert cytostatic effects in rat kidney NRK/KNRK cells (RB, data not shown), confirming that the effect is not idiosyncratic to H4IIEC3 cells. When comparing rat cells to human cells, the human cells were much more sensitive to 5F 203, compared to the rat cells, suggesting an important role for agonism of the AhR. However, TCDD by itself had no significant effect on the proliferation of either cell line, showing that agonism of the AhR by itself is insufficient to affect cell growth. These data suggest that it is a specific interaction of AhR-induced genes with 5F 203 that is responsible for the anti-proliferative activity of 5F 203; one possibility is that cytochrome $\mathrm{P} 450$ is induced, and catalyses the formation of a reactive and cytotoxic intermediate.

In summary, these data identify benzothiazoles as high affinity ligands for the AhR, and as species-specific partial agonists for AhR. Current work is aimed at investigating the molecular nature of the interaction between these ligands and the AhR, and characterising the nature of partial agonism with a variety of AhR ligands. 


\section{Acknowledgements}

The authors wish to thank Declan Brady for excellent technical assistance. RB wishes to acknowledge the Al-Tajir trust for support during her PhD. DRB was funded by a grant from Dow Chemical Company. TDB and MFGS were formerly in receipt of funding from CR-UK. This manuscript is Part 31 in a series entitled "Antitumour benzothiazoles". 


\section{Tables}

\begin{tabular}{|l|l|l|l|}
\hline Compound & $\mathrm{R} 1$ & $\mathrm{R} 2$ & $\mathrm{R} 3$ \\
\hline \hline 5F 203 & $5 \mathrm{~F}$ & $-\mathrm{Me}$ & $-\mathrm{NH}_{2}$ \\
\hline DF 203 & $\mathrm{H}$ & $-\mathrm{Me}$, & $-\mathrm{NH}_{2}$ \\
\hline GW 610 & $5 \mathrm{~F}$ & $-\mathrm{OMe}$ & $-\mathrm{OMe}$ \\
\hline AW 892 & $\mathrm{H}$ & $-\mathrm{OMe}$ & $-\mathrm{OMe}$ \\
\hline IH 445 & $5 \mathrm{~F}$ & $-\mathrm{CCH}$ & $-\mathrm{NH}_{2}$ \\
\hline IH 318 & $5 \mathrm{Br}$ & $-\mathrm{Me}$ & $-\mathrm{NH}_{2}$ \\
\hline
\end{tabular}

Table 1. Structures of 2-aryl-benzothiazoles. The position and substituent of the phenylbenzothiazole ring is given by R1, and the R2 and R3 groups on the 2-phenyl ring is shown. The position of R1, 2 and 3 is shown on the figure.

\begin{tabular}{|c|c|c|c|}
\hline Human Gene & Oligonucleotide sequence & $\begin{array}{l}\text { Genebank } \\
\text { accession No }\end{array}$ & Labels \\
\hline $\begin{array}{l}\text { CYP1A1 } \\
\mathrm{F} \\
\mathrm{R} \\
\mathrm{P}\end{array}$ & $\begin{array}{l}\text { GTT GTG TCT TTG TAA ACC AGT G } \\
\text { CTC ACT TAA CAC CTT GTC GAT A } \\
\text { CAA CCA TGA CCA GAA GCT ATG GGT }\end{array}$ & NC_000015 & FAM-BH1 \\
\hline $\begin{array}{l}A h R \\
\mathrm{~F} \\
\mathrm{R} \\
\mathrm{P}\end{array}$ & $\begin{array}{l}\text { ATA CAG AGT TGG ACC GTT TG } \\
\text { CTT TCA GTA GGG GAG GAT TT } \\
\text { TCA GCG TCA GTT ACC TGA GAG CCA }\end{array}$ & NC_000007.12 & HEX-BH2 \\
\hline $\begin{array}{l}\beta \text {-Actin } \\
\mathrm{F} \\
\mathrm{R} \\
\mathrm{P}\end{array}$ & $\begin{array}{l}\text { GAC ATG GAG AAA ATC TGG C } \\
\text { AGG TCT CAA ACA TGA TCT GG } \\
\text { ACA CCT TCT ACA ATG AGC TGC GTG T }\end{array}$ & NC_000007 & ROX-BH1 \\
\hline
\end{tabular}

Table 2. RT-PCR oligonucleotides primers for human genes. The primers and probes are identified by letters designating the forward $(\mathrm{F})$, and reverse $(\mathrm{R})$ primer or the probe $(\mathrm{P})$, and a number corresponding to the position of the base at the $5^{\prime}$ end of the positive strand of primer or probe in the reference sequence, according to gene bank accession number. Sequences are given from 5' $\rightarrow$ 3'. The Reporter dye is at 5' end of the oligonucleotide, and the quencher dye Black-Hole- 1 or -2 is at 3 ' end. FAM, iscarboxy fluorescein; Hex, hexachlorofluorescein; ROX, 5(6)-carboxy-X-rhodamine 


\begin{tabular}{|l|l|l|l|}
\hline Inducer & $\begin{array}{l}\mathbf{E C}_{\mathbf{5 0}}[\mathbf{n M}] \\
\mathbf{( 9 5 \%} \text { confidence intervals) }\end{array}$ & $\begin{array}{l}\mathbf{K}_{\mathbf{i}}[\mathbf{n M}] \\
\mathbf{9 5 \%} \text { confidence intervals })\end{array}$ & $\mathbf{K}_{\mathbf{i}} / \mathbf{E C}_{\mathbf{5 0}}$ \\
\hline \hline TCDD & $0.06(33-100)$ & $0.37(0.18-1)$ & 6.2 \\
\hline IH 445 & $4(2-10)$ & $0.9(0.05-17)$ & 0.2 \\
\hline 5F 203 & $3000(1300-7700)$ & $2.8(2-5)$ & 0.00093 \\
\hline DF 203 & $3400(900-13000)$ & $9.9(5-19)$ & 0.003 \\
\hline GW 610 & $6500(4000-12000)$ & $6.8(2-30)$ & 0.001 \\
\hline AW 892 & $1900(300-14000)$ & $9.8(4-22)$ & 0.005 \\
\hline
\end{tabular}

Table 3. Data for CYP1A1 mRNA induction and AhR binding in rat. The concentrations that produce half-maximal response $\mathrm{EC}_{50}$ were obtained from log concentration-response curves for CYP1A1 mRNA induction. Inhibition dissociation constant $\left(\mathrm{K}_{\mathrm{i}}\right)$ were obtained from the log concentration-TCDD competitive displacement curves. The $95 \%$ confidence intervals are shown in brackets.

\begin{tabular}{|l|c|c|}
\hline Compound & $\begin{array}{l}\text { H4-IIE-C3 } \\
\mathbf{G I}_{\mathbf{5 0}} \text { [nM] (95\% } \\
\text { confidence intervals) }\end{array}$ & $\begin{array}{l}\text { MCF-7 } \\
\mathbf{G I}_{\mathbf{5 0}}[\mathbf{n M ]} \text { (95\% } \\
\text { confidence intervals) }\end{array}$ \\
\hline \hline TCDD & ND* & ND* $^{*}$ \\
\hline Camptothecin & $67(12-386)$ & $19(6-56)$ \\
\hline IH 445 & $100(40-248)$ & $14(7-24)$ \\
\hline 5F 203 & ND* & $18.7-39)$ \\
\hline DF 203 & $1400(450-4300)$ & $140(51-370)$ \\
\hline GW 610 & $223(133-373)$ & ND* \\
\hline AW 892 & $>10000$ & NP \\
\hline IH 318 & & 18 \\
\hline
\end{tabular}

Table 4. Growth inhibitory potency of compounds in MCF-7 and H4-II-E cells. To assess growth inhibitory activity of the compounds, cultures were plated for $24 \mathrm{~h}$ then treated with varying concentrations of each of the compouns listed. Cell viability was assessed by MTT assay after 3 days exposure. Curves were fitted using the sigmoidal response equation (GraphPad Prism 5.0 Software) and the concentration of compounds that inhibited the growth of cells by $50 \%\left(\mathrm{GI}_{50}\right)$ was estimated. The $95 \%$ confidence intervals are shown in brackets. (ND*) these compounds did not decrease the viability of the cells below the control levels $\left(\mathrm{T}_{0}\right)$ significantly up to $\sim 10 \mu \mathrm{M}$. NP = not performed. 1 DF203 had a biphasic effect on growth inhibition. 


\section{Figure Legends}

FIG. 1. Binding affinity for the AhR. A, Saturation binding isotherm of $\left[{ }^{3} \mathrm{H}\right]-\mathrm{TCDD}$ to rat liver cytosol, performed as described in materials and methods. The X-axis shows the concentration of added $\left[{ }^{3} \mathrm{H}\right]$-TCDD, and the $\mathrm{Y}$-axis shows the concentration of specifically bound $\left[{ }^{3} \mathrm{H}\right]-\mathrm{TCDD}$. Data points represent the mean and Standard Deviation (SD) of triplicate determinations. B, Competitive binding assay with TCDD. Rat liver cytosol was incubated with $1 \mathrm{nM}$ $\left[{ }^{3} \mathrm{H}\right]-\mathrm{TCDD}$ (open triangle), or with the indicated concentration of unlabelled TCDD (filled triangle), with and without an excess of non-specific competitor, TCAOB. Specific binding is given as mean and SD of triplicate determinations. C, Competitive binding of 5F 203 to rat liver cytosol. As for B, but unlabelled 5F 203 was added to compete with the [ $\left.{ }^{3} \mathrm{H}\right]$-TCDD. [ $\left.{ }^{3} \mathrm{H}\right]-$ TCDD without added 5F 203 is shown as a triangle, with the indicated concentration of 5F 203 by circles.

FIG. 2. Kinetics of induction of CYP1A1 RNA in H4IIEC3 cells. A, B. H4IIEC3 cells were treated with $0.5 \%(\mathrm{w} / \mathrm{v}) \mathrm{DMSO}$, or $10 \mathrm{nM}$ TCDD in $0.5 \% \mathrm{DMSO}$, for the indicated period of time. RNA was isolated, and RT-PCR for CYP1A1 (A), $\beta$-actin (filled symbols) and AhR (open symbols) RNAs (B) performed as described in Materials and Methods. $\beta$-actin RNA levels were normalised against input cDNA, and AhR and CYP1A1 RNAs were normalised against $\beta$-actin; all are presented as a \% of vehicle control at four hours; all data points represent duplicate PCR determinations of quadruplicate biological replicates, and are shown as mean and SD. Samples that are significantly different from concurrent control (DMSO) at $\mathrm{P}<0.05$ are indicated by an asterisk. C, D. As for A/B, but cells were treated with DMSO (squares), TCDD (circles) or 1 $\mu \mathrm{M} 5 \mathrm{~F} 203$ (triangles).

FIG. 3. Induction of CYP1A1 RNA by benzothiazoles. A, B. As for Figure 2, but cells were exposed to compound for $4 \mathrm{~h}$ in $0.1 \%(\mathrm{w} / \mathrm{v})$ DMSO vehicle, and compound concentration is shown on the X-axis. CYP1A1/ $\beta$-actin ratios are normalised to the maximal induced level attained with TCDD, which is set as $100 \%$ response. Curves were fitted to the data using the variable slope sigmoid Hill equation, as described in materials and methods. In A, TCDD is shown with a filled circle, whereas 5F 203 is shown with an open circle. B, $\beta$-actin RNA is shown with filled symbols, whereas the AhR/ $\beta$-actin ratio is shown with open symbols. Each point represents the mean and SD of triplicate samples. C, D. As for A/B, but using benzothiazole compounds GW 610 (inverted triangle), AW 892 (square), DF 203 (diamond) and IH 445 (triangle). The TCDD data from A are shown in C/D for comparison, and dose-response curves were nor- 
malised to maximal TCDD response by including a 10 nM TCDD treatment group in each experiment. D, $\beta$-actin RNA is shown with filled symbols, whereas the AhR/ $\beta$-actin ratio is shown with open symbols.

\section{FIG. 4. 5F 203, but not IH 445, antagonises the induction of CYP1A1 by TCDD in}

H4IIEC3 cells. A, B. H4IIEC3 cells were exposed for $4 \mathrm{~h}$ to TCDD alone (filled circles), TCDD and $1 \mu \mathrm{M}$ 5F 203 (open circles) or $1 \mu \mathrm{M}$ 5F 203 alone (open square). RNA was then isolated, and RT-PCR for CYP1A1/ $\beta$-actin ratio (A), or $\beta$-actin and AhR/ $\beta$-actin (B) performed as described in Figure 3. C, D. As for A/B, but cells were exposed to TCDD alone (circle), TCDD plus $100 \mathrm{nM}$ (diamonds), $300 \mathrm{nM}$ (squares), or $1 \mu \mathrm{M}$ 5F 203 (inverted triangle), or 5F 203 alone (triangle). Curves were fitted using a sigmoidal Hill slope, with a constant slope of 1. E, F. As for A/B, but H4IIEC3 cells were dosed with TCDD alone (filled circles), TCDD plus 3 nM IH 445 (open circles), or IH 445 alone (open squares).

\section{FIG. 5. 5F 203 does not antagonise the induction of CYP1A1 RNA by TCDD in MCF-7}

cells. A, B. MCF-7 cells were treated with $0.1 \% \mathrm{DMSO}(\mathrm{w} / \mathrm{v})$, or the indicated concentration of TCDD (filled circle) or 5F 203 (open circles), and RNA isolated after $4 \mathrm{~h}$ treatment. RT-PCR was carried out as described in materials and methods, and A shows CYP1A1/ $\beta$-actin ratio, whereas $B$ shows $\beta$-actin RNA, and the AhR/ $\beta$-actin ratio. $C, D$. As for $A / B$, but cells were treated with TCDD alone (filled circles), TCDD plus 500 pM 5F 203 (open circles), or 5F 203 alone (open square).

FIG. 6. Cytostatic effect of benzothiazoles in H4IIEC3 and MCF-7 cells. A, H4IIEC3 cells were seeded and incubated for one day, then treated with the indicated concentration of 5F 203 (filled squares), Camptothecin (filled circles), TCDD (open circles), IH 445 (filled inverted triangles), or $0.1 \%$ DMSO (vehicle control), for three days. MTT assay was performed at the time of addition of drug (shown by $\mathrm{T}_{0}$, and a dotted horizontal line), and after three days incubation with drug, followed by measuring absorbance at $590 \mathrm{~nm}$. Results are mean and SD of triplicate biological replicates. B, as for A, but in MCF-7 cells. 


\section{References}

Abdelrahim, M., Newman, K., Vanderlaag, K., Samudio, I., and Safe, S. (2006). 3,3 'Diindolylmethane (DIM) and its derivatives induce apoptosis in pancreatic cancer cells through endoplasmic reticulum stress-dependent upregulation of DR5. Carcinogenesis 27, 717-728.

Backlund, M., and Ingelman-Sundberg, M. (2005). Regulation of aryl hydrocarbon receptor signal transduction by protein tyrosine kinases. Cell. Signal. 17, 39-48.

Backlund, M., Johansson, I., Mkrtchian, S., and IngelmanSundberg, M. (1997). Signal transduction-mediated activation of the aryl hydrocarbon receptor in rat hepatoma H4IIE cells. J. Biol. Chem. 272, 31755-31763.

Bell, D. R., Clode, S., Fan, M. Q., Fernandes, A., Foster, P. M., Jiang, T., Loizou, G., MacNicoll, A., Miller, B. G., Rose, M., Tran, L., and White, S. (2007). Relationships between tissue levels of 2,3,7,8-tetrachlorodibenzo-p-dioxin (TCDD), mRNAs, and toxicity in the developing male Wistar(Han) rat. Toxicol Sci 99, 591-604.

Boronat, S. (2007). Modulation of aryl hydrocarbon receptor transactivation by carbaryl, a nonconventional ligand (vol 274, pg 3327, 2007). Febs J. 274, 4347-4347.

Bradfield, C. A., Kende, A. S., and Poland, A. (1988). Kinetic and equilibrium studies of Ah receptor-ligand binding: use of [125I]2-iodo-7,8-dibromodibenzo-p-dioxin. Mol Pharmacol 34, 229-237.

Bradshaw, T. D., Chua, M. S., Browne, H. L., Trapani, V., Sausville, E. A., and Stevens, M. F. G. (2002). In vitro evaluation of amino acid prodrugs of novel antitumour 2-(4-amino3-methylphenyl)benzothiazoles. Br. J. Cancer 86, 1348-1354.

Brantley, E., Trapani, V., Alley, M. C., Hose, C. D., Bradshaw, T. D., Stevens, M. F. G., Sausville, E. A., and Stinson, S. F. (2004). Fluorinated 2-(4-amino-3-methylphenyl) benzothiazoles induce CYP1A1 expression, become metabolized, and bind to macromolecules in sensitive human cancer cells. Drug Metab. Dispos. 32, 1392-1401.

Chen, I., McDougal, A., Wang, F., and Safe, S. (1998). Aryl hydrocarbon receptor-mediated antiestrogenic and antitumorigenic activity of diindolylmethane. Carcinogenesis 19, 1631-1639.

Christou, M., Savas, U., Spink, D. C., Gierthy, J. F., and Jefcoate, C. R. (1994). COEXPRESSION OF HUMAN CYP1A1 AND A HUMAN ANALOG OF CYTOCHROME P450-EF IN RESPONSE TO 2,3,7,8-TETRACHLORO-DIBENZO- 


\section{P-DIOXIN IN THE HUMAN MAMMARY CARCINOMA-DERIVED MCF-7}

CELLS. Carcinogenesis 15, 725-732.

Chua, M. S., Kashiyama, E., Bradshaw, T. D., Stinson, S. F., Brantley, E., Sausville, E. A., and Stevens, M. F. G. (2000). Role of CYP1A1 in modulation of antitumor properties of the novel agent 2-(4-amino-3-methylphenyl)benzothiazole (DF 203, NSC 674495) in human breast cancer cells. Cancer Res. 60, 5196-5203.

de Medina, P., Casper, R., Savouret, J. F., and Poirot, M. (2005). Synthesis and biological properties of new stilbene derivatives of resveratrol as new selective aryl hydrocarbon modulators. J Med Chem 48, 287-291.

Dzeletovic, N., McGuire, J., Daujat, M., Tholander, J., Ema, M., FujiiKuriyama, Y., Bergman, J., Maurel, P., and Poellinger, L. (1997). Regulation of dioxin receptor function by omeprazole. J. Biol. Chem. 272, 12705-12713.

Ema, M., Ohe, N., Suzuki, M., Mimura, J., Sogawa, K., Ikawa, S., and Fujii-Kuriyama, Y. (1994). Dioxin binding activities of polymorphic forms of mouse and human arylhydrocarbon receptors. J Biol Chem 269, 27337-27343.

Henry, E. C., Bemis, J. C., Henry, O., Kende, A. S., and Gasiewicz, T. A. (2006). A potential endogenous ligand for the aryl hydrocarbon receptor has potent agonist activity in vitro and in vivo. Arch. Biochem. Biophys. 450, 67-77.

Hestermann, E. V., and Brown, M. (2003). Agonist and chemopreventative ligands induce differential transcriptional cofactor recruitment by aryl hydrocarbon receptor. Mol. Cell. Biol. 23, 7920-7925.

Hestermann, E. V., Stegeman, J. J., and Hahn, M. E. (2000). Relative contributions of affinity and intrinsic efficacy to aryl hydrocarbon receptor ligand potency. Toxicol Appl Pharmacol 168, 160-172.

Holmes, J. L., and Pollenz, R. S. (1997). Determination of aryl hydrocarbon receptor nuclear translocator protein concentration and subcellular localization in hepatic and nonhepatic cell culture lines: development of quantitative Western blotting protocols for calculation of aryl hydrocarbon receptor and aryl hydrocarbon receptor nuclear translocator protein in total cell lysates. Mol Pharmacol 52, 202-211.

Hutchinson, I., Chua, M. S., Browne, H. L., Trapani, V., Bradshaw, T. D., Westwell, A. D., and Stevens, M. F. G. (2001). Antitumor benzothiazoles. 14. Synthesis and in vitro biological properties of fluorinated 2-(4-aminophenyl)benzothiazoles. J. Med. Chem. 44, 1446-1455. 
Kenakin, T. (1997). Pharmacologic analysis of drug-receptor interaction. 227 East Washington Square, Philadelphia, PA 19106-3780, Lippincott-Raven Publishers.

Leong, C. O., Gaskell, M., Martin, E. A., Heydon, R. T., Farmer, P. B., Bibby, M. C., Cooper, P. A., Double, J. A., Bradshaw, T. D., and Stevens, M. F. G. (2003). Antitumour 2-(4aminophenyl)benzothiazoles generate DNA adducts in sensitive tumour cells in vitro and in vivo. Br. J. Cancer 88, 470-477.

Loaiza-Pérez, A. I., Trapani, V., Hose, C., Singh, S. S., Trepel, J. B., Stevens, M. F. G., Bradshaw, T. D., and Sausville, E. A. (2002). Aryl hydrocarbon receptor mediates sensitivity of MCF-7 breast cancer cells to antitumor agent 2-(4-amino-3methylphenyl) benzothiazole. Mol. Pharmacol. 61, 13-19.

MacDonald, C. J., Ciolino, H. P., and Yeh, G. C. (2004). The drug salicylamide is an antagonist of the aryl hydrocarbon receptor that inhibits signal transduction induced by 2,3,7,8-tetrachlorodibenzo-p-dioxin. Cancer Res. 64, 429-434.

McDougal, A., Wilson, C., and Safe, S. (1997). Inhibition of 7,12-dimethylbenz[a]anthraceneinduced rat mammary tumor growth by aryl hydrocarbon receptor agonists. Cancer Lett 120, 53-63.

Palermo, C. M., Hernando, J. I. M., Dertinger, S. D., Kende, A. S., and Gasiewicz, T. A. (2003). Identification of potential aryl hydrocarbon receptor antagonists in green tea. Chem. Res. Toxicol. 16, 865-872.

Poland, A., Clover, E., Kende, A. S., DeCamp, M., and Giandomenico, C. M. (1976). 3,4,3',4'Tetrachloro azoxybenzene and azobenzene: potent inducers of aryl hydrocarbon hydroxylase. Science 194, 627-630.

Poland, A., and Knutson, J. C. (1982). 2,3,7,8-tetrachlorodibenzo-p-dioxin and related halogenated aromatic hydrocarbons: examination of the mechanism of toxicity. Annu Rev Pharmacol Toxicol 22, 517-554.

Poland, A., Palen, D., and Glover, E. (1994). ANALYSIS OF THE 4 ALLELES OF THE MURINE ARYL-HYDROCARBON RECEPTOR. Mol. Pharmacol. 46, 915-921.

Safe, S., Fujita, T., Romkes, M., Piskorskapliszczynska, J., Homonko, K., and Denomme, M. A. (1986). PROPERTIES OF THE 2,3,7,8-TCDD RECEPTOR - A QSAR APPROACH. Chemosphere 15, 1657-1663.

Sawyer, T., and Safe, S. (1982). PCB isomers and congeners: induction of aryl hydrocarbon hydroxylase and ethoxyresorufin O-deethylase enzyme activities in rat hepatoma cells. Toxicol Lett 13, 87-93. 
Trapani, V., Patel, V., Leong, C. O., Ciolino, H. P., Yeh, G. C., Hose, C., Trepel, J. B., Stevens, M. F., Sausville, E. A., and Loaiza-Pérez, A. I. (2003). DNA damage and cell cycle arrest induced by 2-(4-amino-3-methylphenyl)-5-fluorobenzothiazole (5F 203, NSC 703786) is attenuated in aryl hydrocarbon receptor deficient MCF-7 cells. $\mathrm{Br} J$ Cancer 88, 599-605.

Whitlock, J. P., Jr. (1999). Induction of cytochrome P4501A1. Annu Rev Pharmacol Toxicol 39, $103-125$.

Willett, K. L., Randerath, K., Zhou, G. D., and Safe, S. H. (1998). Inhibition of CYP1A1dependent activity by the polynuclear aromatic hydrocarbon (PAH) fluoranthene. Biochem. Pharmacol. 55, 831-839.

Zhang, S., Qin, C. H., and Safe, S. H. (2003). Flavonoids as aryl hydrocarbon receptor agonists/antagonists: Effects of structure and cell context. Environ. Health Perspect. 111, $1877-1882$.

Zhang, S., Rowlands, C., and Safe, S. (2008). Ligand-dependent interactions of the Ah receptor with coactivators in a mammalian two-hybrid assay. Toxicol. Appl. Pharmacol. 227, 196-206.

Zhou, J. G., and Gasiewicz, T. A. (2003). 3 '-Methoxy-4 '-nitroflavone, a reported aryl hydrocarbon receptor antagonist, enhances Cypla1 transcription by a dioxin responsive element-dependent mechanism. Arch. Biochem. Biophys. 416, 68-80.

Zhou, J. G., Henry, E. C., Palermo, C. M., Dertinger, S. D., and Gasiewicz, T. A. (2003). Species-specific transcriptional activity of synthetic flavonoids in guinea pig and mouse cells as a result of differential activation of the aryl hydrocarbon receptor to interact with dioxin-responsive elements. Mol. Pharmacol. 63, 915-924. 


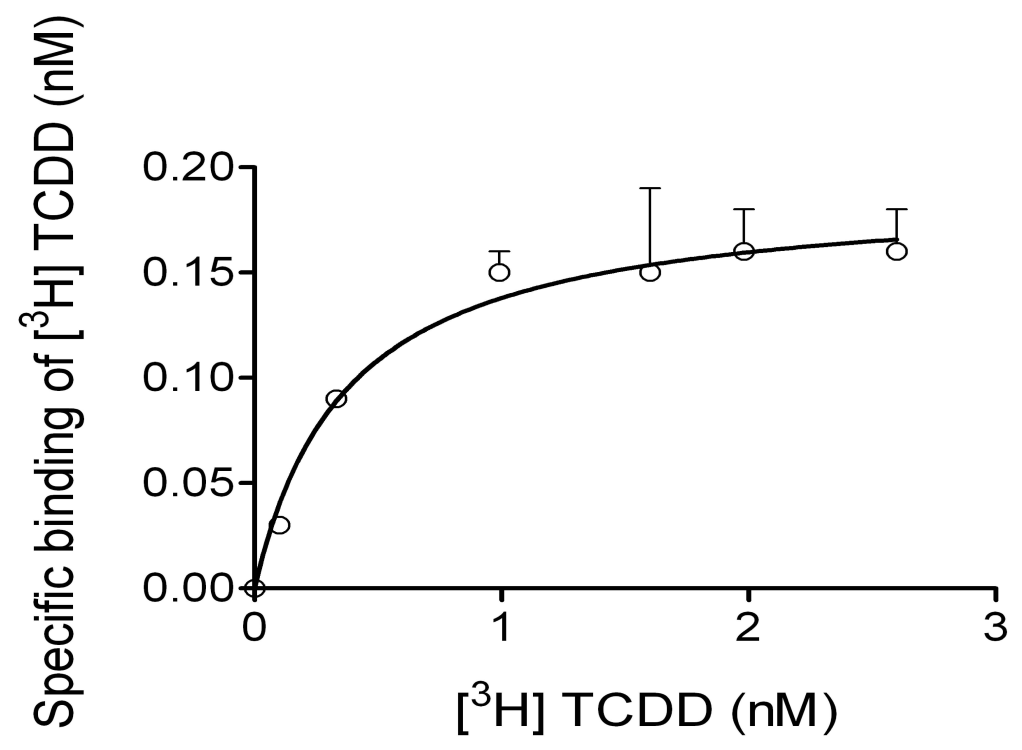

B

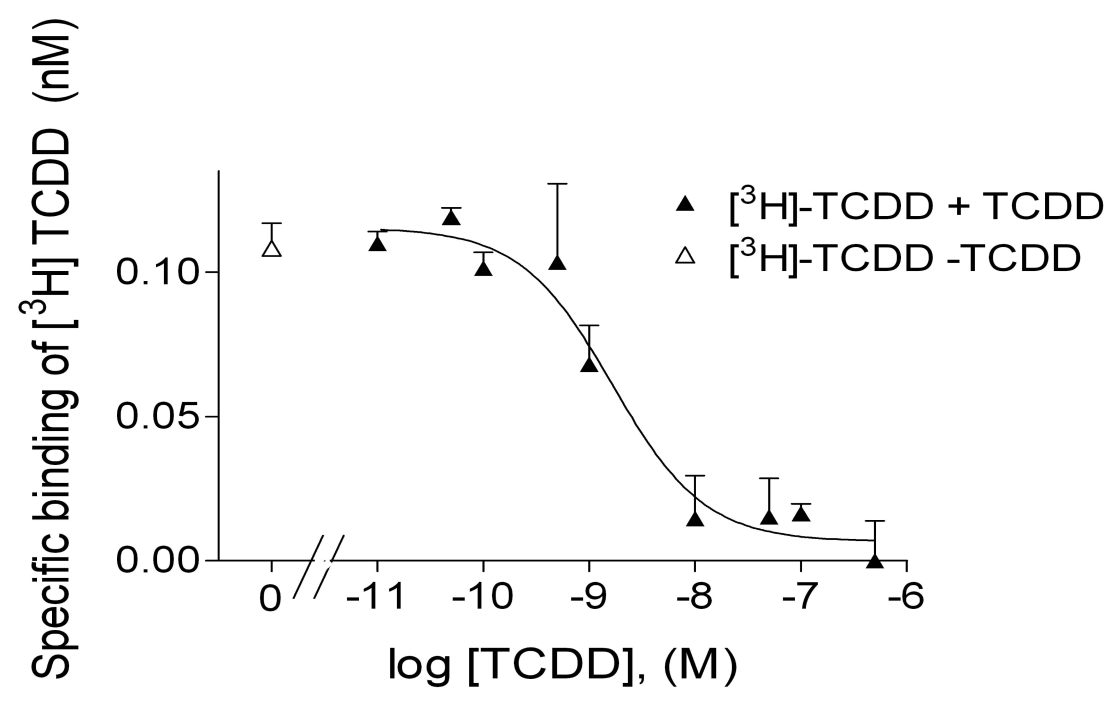

C

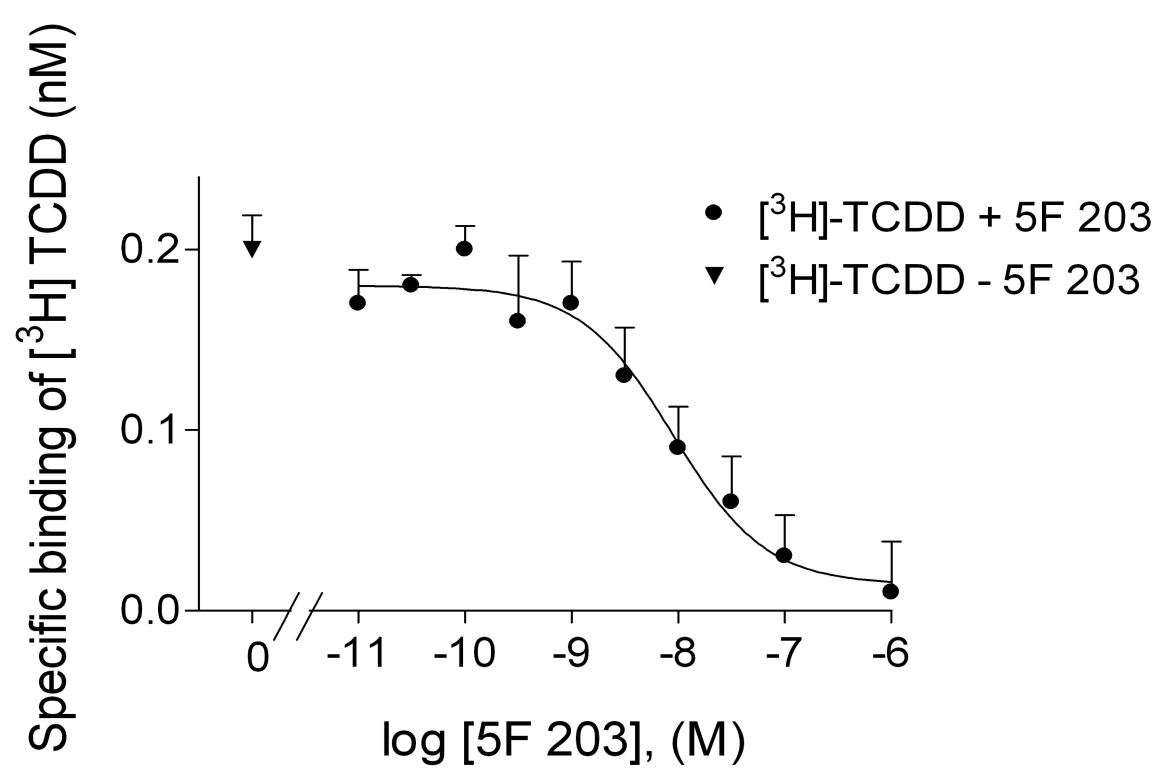

Figure 1 

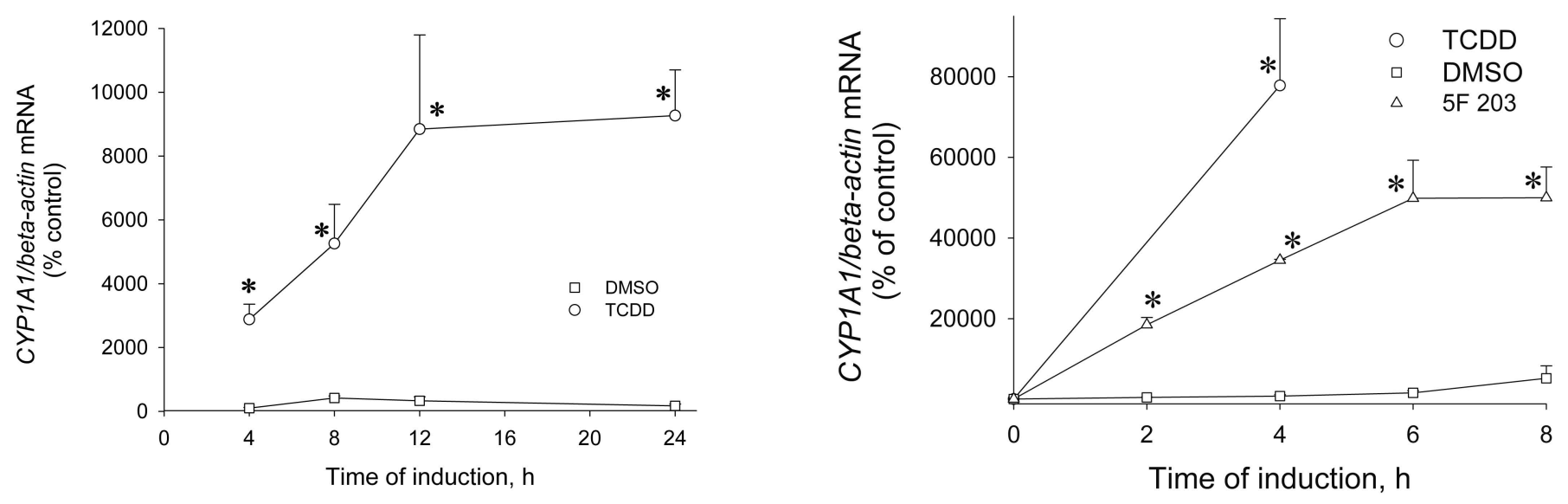

B
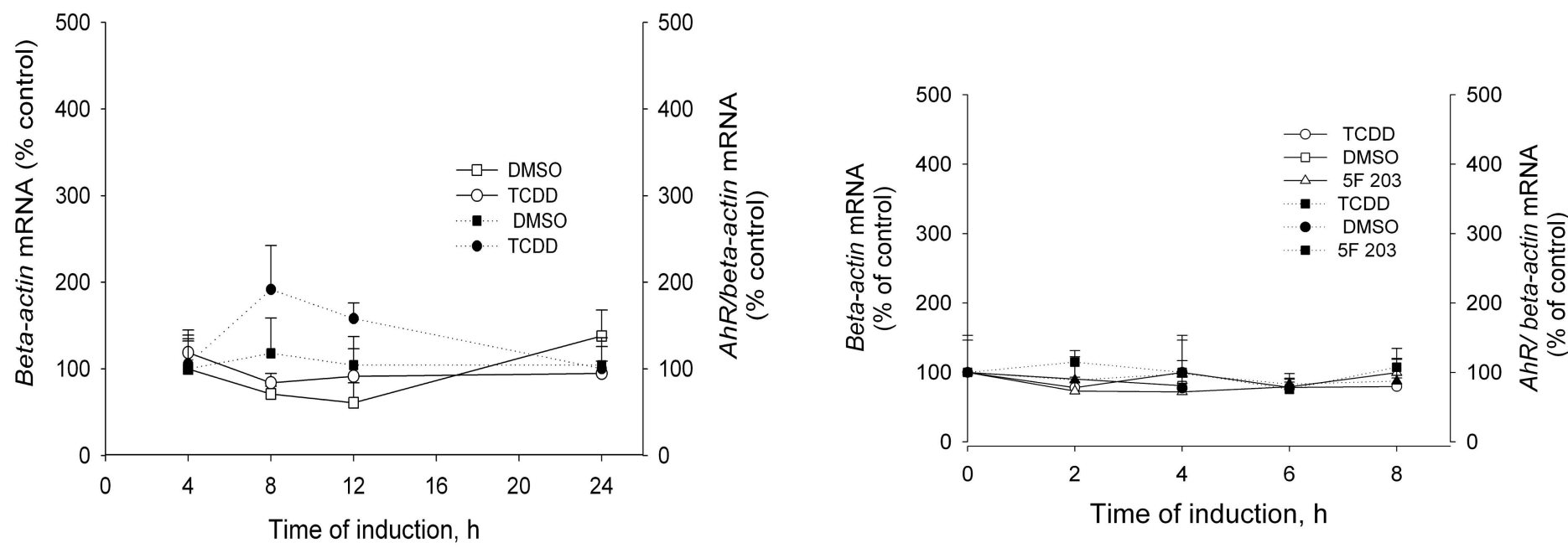

Figure 2 

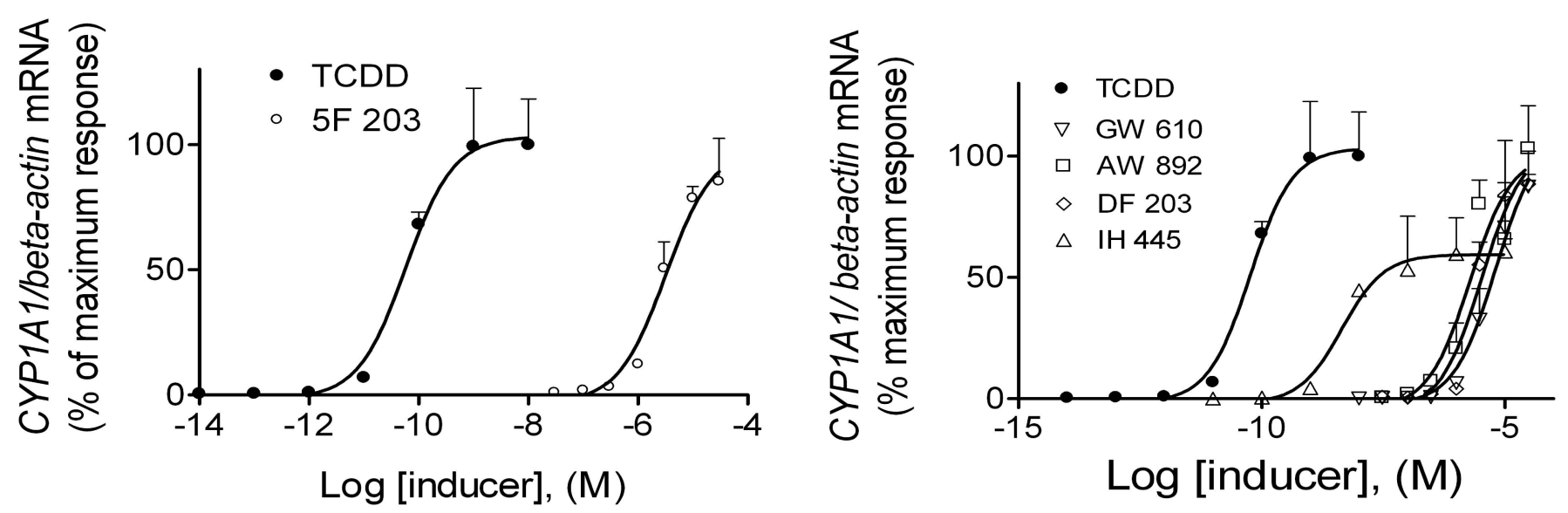

\section{B}

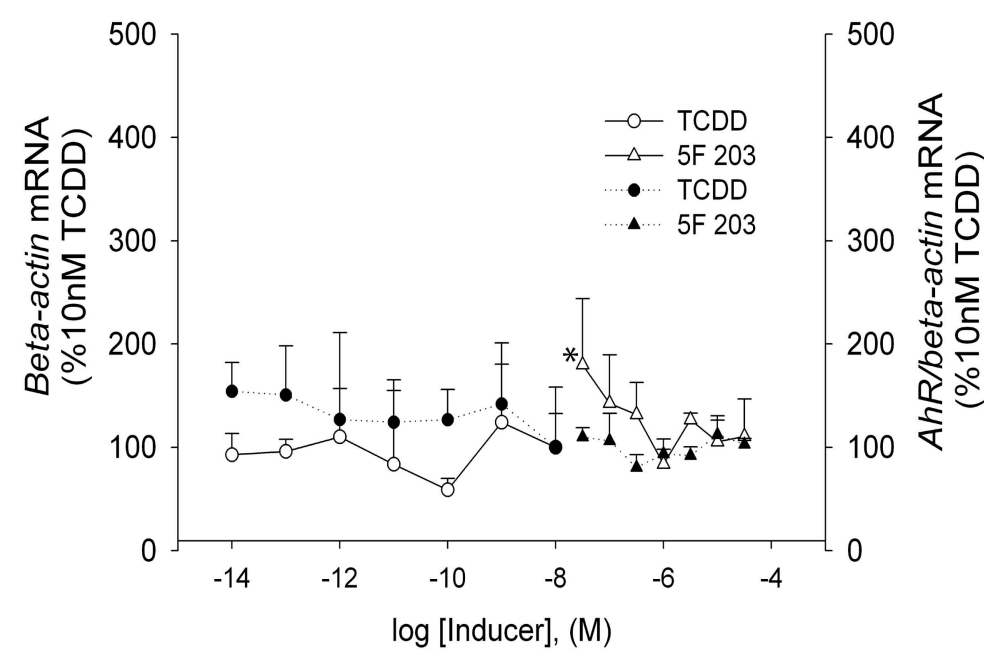

D

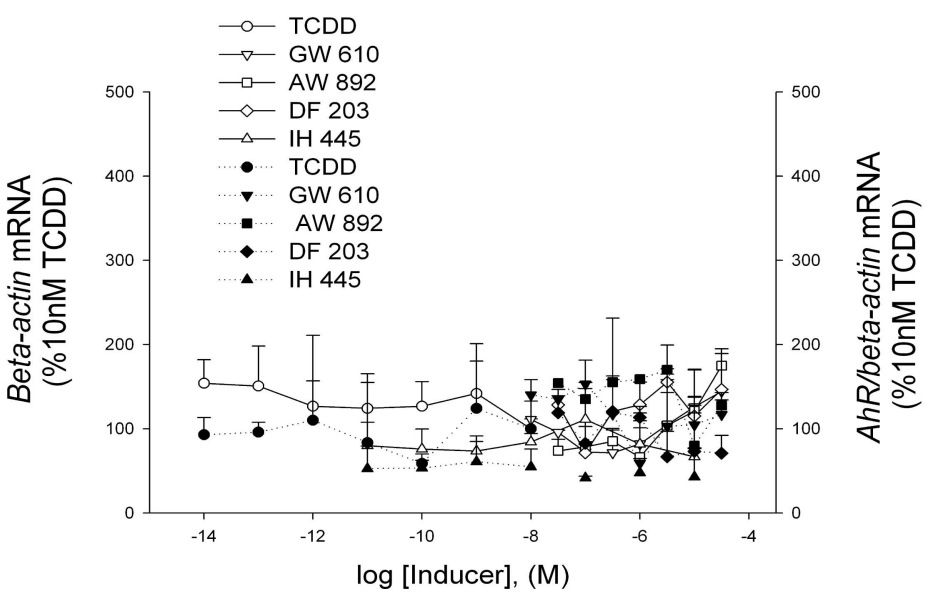

Figure 3 


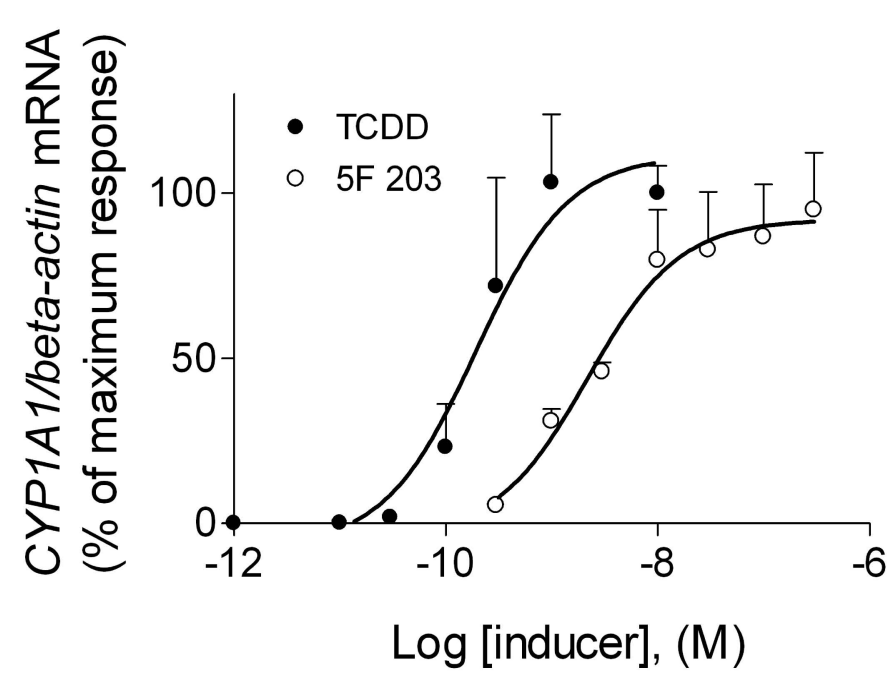

B

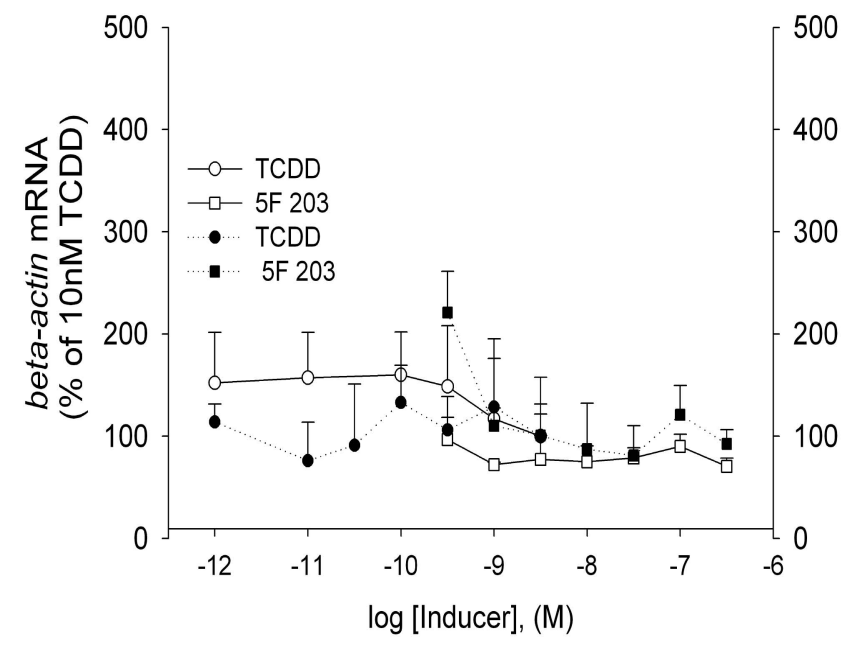

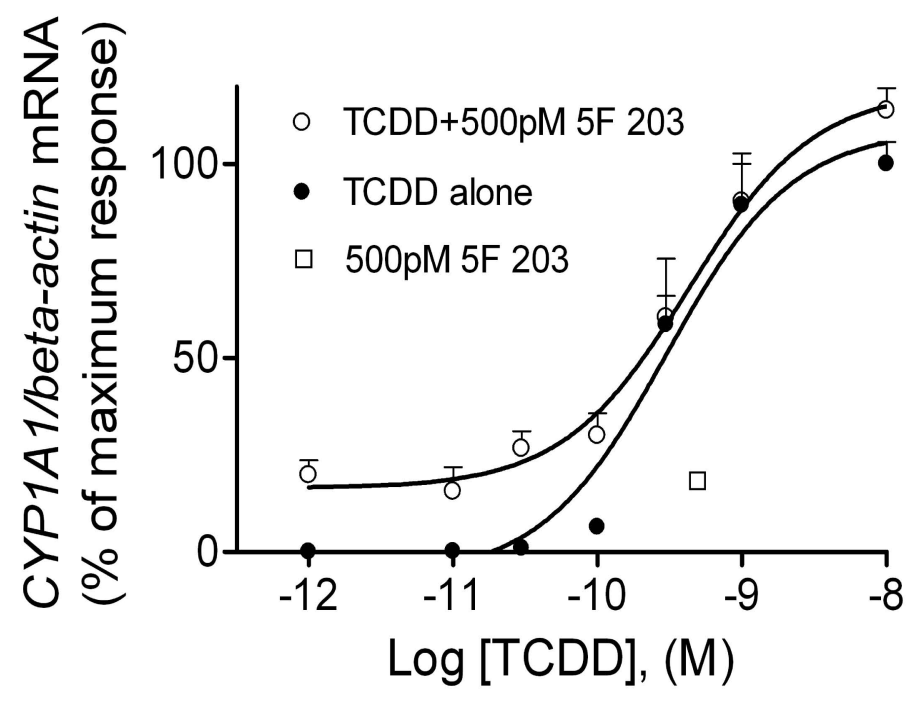

D

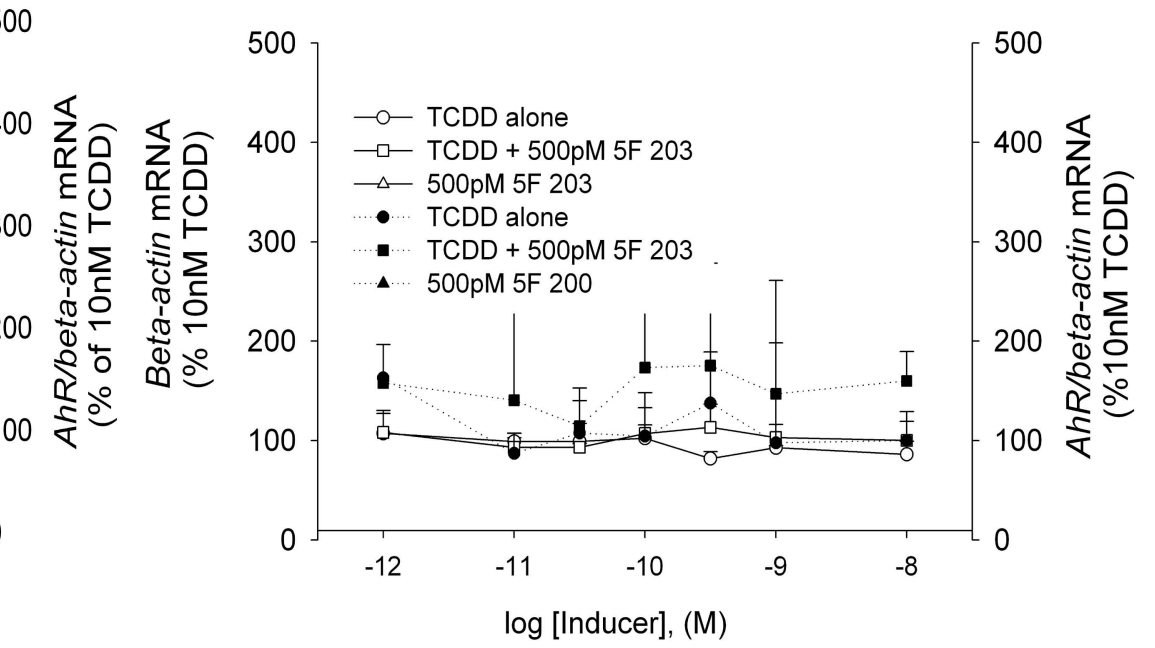

Figure 5 


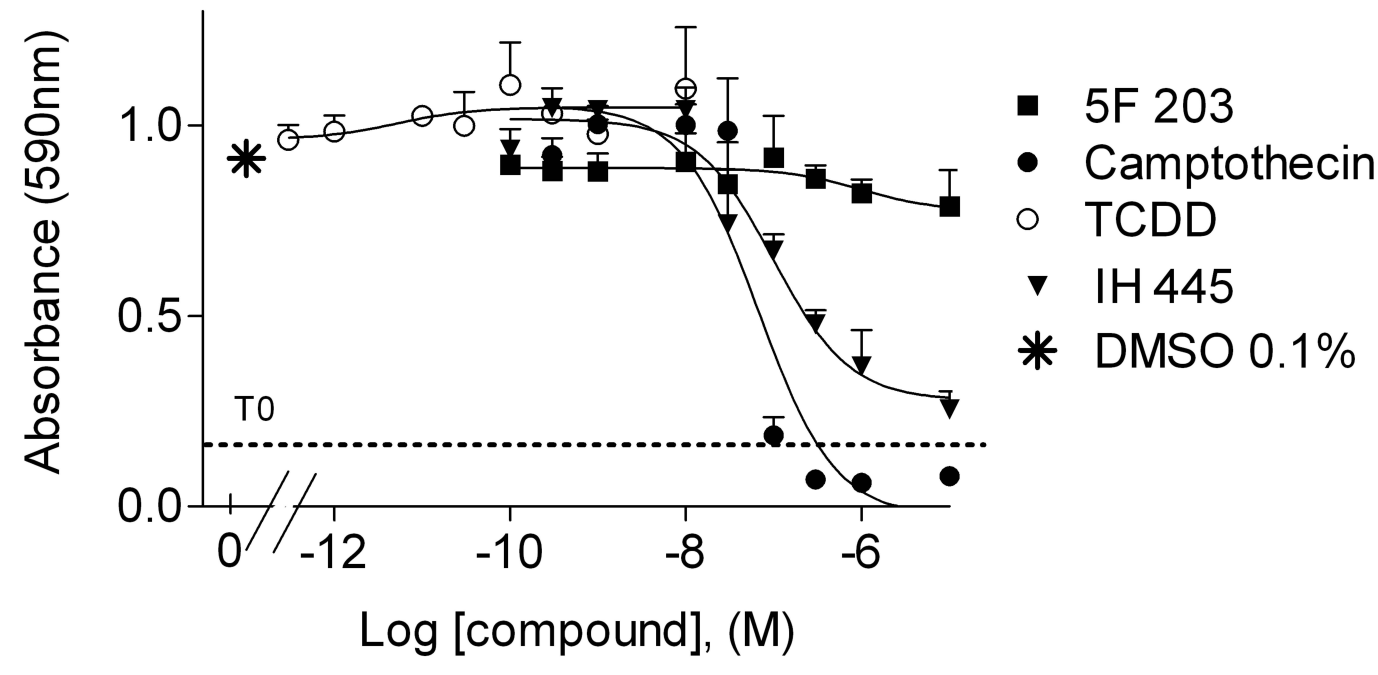

\section{B}

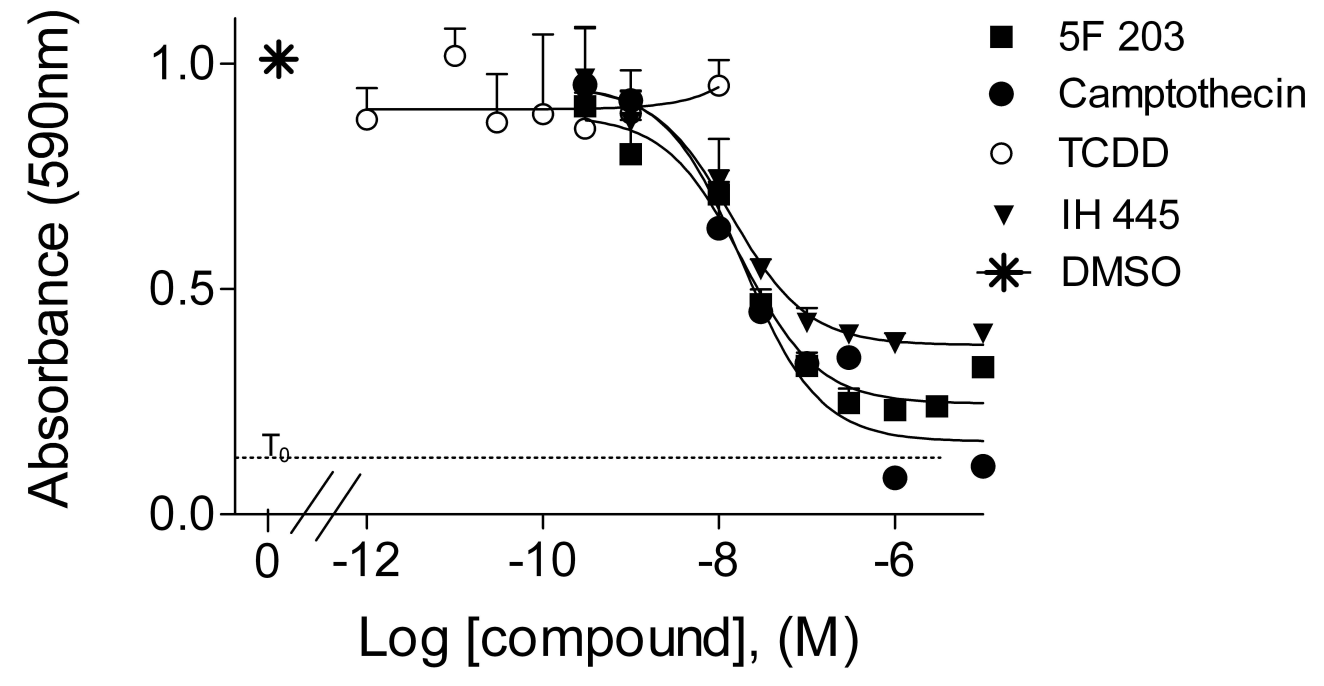

